\title{
Representações sonoras do diabo no cinema: vozes múltiplas e músicas mínimas em O Exorcista ${ }^{1}$
}

\section{Sonic representations of the devil in films: multiple voices and minimal music in The Exorcist}

\section{Rodrigo Carreiro}

Professor do Programa de Pós-Graduação em Comunicação da Universidade Federal de Pernambuco. É Mestre e Doutor em Comunicação pela UFPE. Pesquisa principalmente sobre filmes de horror, sound design e análise fílmica.

<rcarreiro@gmail.com>

\section{Suzana Reck Miranda}

Professora do Programa de Pós-Graduação em Imagem e Som da Universidade Federal de São Carlos. É Mestre e Doutora em Multimeios pela Unicamp. Pesquisa principalmente sobre música, som e cinema.

< suzana_miranda@yahoo.com>

\section{RESUMO}

O diabo tem sido, ao longo dos séculos, um dos personagens favoritos das artes figurativas, inclusive $o$ cinema - que o tem representado de diversas maneiras e nos mais variados gêneros. Suas diferentes aparências vêm sendo documentadas e examinadas em detalhes, mas sua contraparte sonora não tem recebido a mesma atenção. É objetivo deste ensaio, portanto, examinar e discutir algumas das mais influentes maneiras como o diabo tem sido representado nos filmes, em termos sonoros. Faremos isso através da análise dos usos da voz, da música e dos efeitos sonoros em O Exorcista (William Friedkin, 1973). A escolha deste filme se deve à influência massiva que ele teve na representação do diabo no cinema de horror das últimas cinco décadas.

Palavras-chave: Sound design. Cultura pop. Diabo. Horror. Análise fílmica.

\begin{abstract}
The devil has been, over the centuries, one of the favorite characters of figurative arts, including cinema - that has represented in various ways and in various genres. Their different appearances have been documented and examined in detail, but its sound counterpart has not received the same attention. It is the aim of this essay, therefore, to examine and discuss some of the most influential ways in which the devil has been depicted in movies in sonic terms. We will do this by analyzing the use of voice, music and sound effects in The Exorcist (William Friedkin, 1973). We choose this film due to the massive influence he had on Devil's representation in horror cinema of the past five decades.
\end{abstract}

Keywords: Sound design. Pop culture. Devil. Horror. Film analysis.

\section{Introdução}

Antes mesmo de ganhar um nome na mitologia da Igreja Católica, o diabo - compreendido aqui como a representação, em um símbolo concreto,

1 Uma versão preliminar deste artigo foi apresentada no 24 Encontro da Compós, dentro do GT Estudos de Som e Música. O evento ocorreu em Brasília (DF), de 9 a 12 de junho de 2015. 
do conceito filosófico do Mal - já era um dos motivos visuais favoritos dos praticantes das artes figurativas. Um dos mais antigos sítios arqueológicos conhecidos que contém pinturas rupestres, a caverna de Trois-Frères, na França, apresenta uma dessas imagens, pintada há pelo menos 50 mil anos: a figura de um ser humano com um crânio de cervo (incluindo chifres) sobre a cabeça. $\mathrm{Na}$ época em que a imagem foi pintada, não existiam religiões organizadas e nem mesmo a linguagem verbal havia sido desenvolvida, mas o uso artístico de uma imagem para representar concretamente a noção abstrata do mal já estava posto.

Pintores, escultores, escritores e artistas em geral têm procurado representar o mal com muita frequência, e das mais diferentes maneiras. Não foi por acaso que Luther Link (1998), historiador da arte que mapeou as representações do diabo na arte figurativa através dos tempos, deu ao estudo denominado $O$ diabo o subtítulo $A$ máscara sem rosto. De modo geral, somente a partir do século IX, já na Idade Média, a figura do mal começou a ganhar representações visuais um pouco mais recorrentes, sobretudo a partir de pintores e escultores que retratavam episódios bíblicos, na maioria das vezes sob encomenda feita por padres e bispos da Igreja Católica (Link, 1995).

Desde então, a figura do diabo mais conhecida costuma ter alguns (ou todos) os elementos listados a seguir: chifres, barbicha, cauda pontuda, pele vermelha, tridente, patas de bode. Em geral, esses elementos eram herdados de divindades pagãs e/ou de cultos politeístas, contra os quais a Igreja Católica investiu, historicamente, na tentativa de deter a hegemonia religiosa no ocidente. Mesmo naquela época, porém, essas representações visuais ainda variavam, ao contrário do que acontecia com símbolos da iconografia religiosa que representam o bem. $O$ diabo podia ser representado como uma serpente, um touro, uma ave, um anjo ou ser humano disfarçado, uma fogueira, e tantos outros motivos visuais. Essa extensa variedade de representações deu a este personagem do folclore cristão, na cultura popular, a fama de ser um perito de disfarces.

É possível que as múltiplas representações sejam uma das razões para que o diabo permaneça, através dos séculos, como um dos motivos visuais favoritos dos artistas. Muitos historiadores e pesquisadores do tema (Link, 1995; Muchembled, 2001; Schreck, 2001; Mitchell, 2002; Stanford, 2003; Rickels, 2008; Guerra, 2011) atestam que, nas suas muitas formas, o diabo tem sido figura frequente na produção artística ocidental desde a Idade Média.

Não é diferente no cinema. Já em 1896, apenas um ano após a primeira exibição pública de filmes pelos irmãos Lumière, o diabo já era personagem 
de pelo menos um curta-metragem: Le Manoir du Diable, onde foi interpretado pelo próprio diretor, Georges Mèliés. Uma consulta simples ao principal banco de dados sobre cinema no mundo, o Internet Movie Database (IMDb), registra um total de 1.565 filmes (ou produções de TV) que apresentam o diabo como personagem, até o ano de 2014. Para efeito de comparação, outros personagens da cultura popular igualmente famosos possuem presença bem mais tímida nas telas: Jesus Cristo surgiu em 685 filmes no mesmo período; Drácula, em 259 títulos; e Frankenstein, em 256 produções.

A ampla variedade de formas com que foi figurativamente representado deu ao diabo uma imagem permanentemente mutante nos filmes. Ele podia aparecer como um animal, um ser humano, um ser mitológico ou um monstro, entre outras possibilidades - inclusive detendo a capacidade sobrenatural de mudar de forma dentro do mesmo filme. Apesar dessa instabilidade, o mais conhecido especialista no tema, Schreck (2001), admite que a representação visual do diabo segue duas vertentes principais. Na primeira vertente, o diabo possui forma humana - quase sempre, um homem charmoso e sedutor, às vezes acrescido de um elemento exótico e/ou sombrio. Títulos como O Diabo Disse Não (Heaven Can Wait, Ernst Lubitsch, 1943), Coração Satânico (Angel Heart, Alan Parker, 1985) e O Advogado do Diabo (The Devil's Advocate, Taylor Hackford, 1997) se enquadram nesse filão.

A segunda vertente é formada basicamente pelos filmes de horror. Nesses filmes, que eram relativamente escassos até o começo dos anos 1970 e se tornaram muito populares a partir dessa época, o diabo passou a encarnar o arquétipo do monstro - um arquétipo obrigatório para garantir o pertencimento do filme ao gênero, de acordo com Carroll (1999). Assim sendo, a representação figurativa do diabo se tornou menos sedutora e mais repelente; o personagem responde pelo florescimento do afeto do horror, que dá nome ao gênero. Em filmes como A Noite do Demônio (The Night of the Demon, Jacques Tourneur, 1957), O Bebê de Rosemary (Rosemary`s Baby, Roman Polanski, 1968) e O Exorcista (The Exorcist, William Friedkin, 1973), o diabo é representado fundamentalmente como uma criatura monstruosa, repulsiva e ameaçadora, da qual queremos a maior distância possível.

As representações visuais do diabo no cinema têm sido bem estudadas (Mitchell, 2002) e documentadasiconograficamente(Schreck, 2001).O foco deste ensaio, contudo, procura deslocar esse interesse para um tipo de representação pouco explorado nas pesquisas sobre cinema: as representações sonoras do diabo. Nas próximas páginas, procuraremos discutir e examinar padrões de uso da voz, da música e de efeitos sonoros em filmes que materializam a presença 
do diabo como um personagem habitante da diegese. Tomaremos como estudo de caso o mais influente filme das últimas cinco décadas a explorar o diabo como personagem: $O$ Exorcista.

\section{Contexto histórico}

Antes de examinar os aspectos sonoros do filme de William Friedkin relacionados à representação do diabo, é importante circunscrever rapidamente o contexto histórico da produção, bem como delimitar corretamente seu raio de influência no cinema comercial. Financiada pelo estúdio Warner Brothers, a produção de $O$ Exorcista começou a partir do grande sucesso do livro homônimo de William Peter Blatty, lançado em 1971. O romance, alegadamente inspirado em um caso real ocorrido em 1949, em Maryland (EUA), frequentara por semanas o topo da lista de mais vendidos do New York Times, no rastro de um debate intelectual estampado na capa da revista Time de outubro de 1966, a respeito da suposta morte de Deus (Newman, 2011).

O debate, nascido entre estudiosos de teologia, se materializou como um fenômeno da cultura pop importante nos Estados Unidos, tendo gerado uma onda de interesse do público por religiões pagãs e pelo satanismo (concebido tanto como religião quanto como ciência, para algumas pessoas). No cinema, o primeiro longa-metragem a tratar do assunto com sucesso foi $O$ Bebê de Rosemary (Rosemary's Baby, Roman Polanski, 1968), apontado por muitos historiadores (Schreck, 2001; Cherry, 2009; Newman, 2011) como o título que disparou uma onda massiva de realizações cinematográficas tendo o diabo (quase sempre inserido na mitologia católico-cristã) como tema central ${ }^{2}$, e que incluem, além de $O$ Exorcista, outros longas que fizeram bastante sucesso na época, como Balada para Satã (The Mephisto Waltz, Paul Wendkos, 1871), A Irmandade de Satanás (Brotherhood of Satan, Bernard McEveety, 1971) e A Profecia (The Omen, Richard Donner, 1976).

Assim, embora filmes que traziam o demônio para a diegese já chamassem a atenção do público desde a virada das décadas de 1960 e 1970, o sucesso de O Exorcista - faturamento global de US\$ 441 milhões, transformando-o no filme de horror de maior público até hoje - colocou a figura do diabo no mainstream. Tamanho sucesso, claro, não passou despercebido a produtores e cineastas de todo o mundo. Uma das consequências foi o aumento vertiginoso no número

2 Apesar de tão influente quanto O Exorcista, o filme de Polanski não serve para o propósito deste ensaio, pois nele o diabo não aparece como personagem da diegese, com exceção de uma breve sequência de poucos segundos, que traduz em imagens e sons um pesadelo da personagem de Mia Farrow. 
de produções com enredos ligados ao satanismo. Outra, que nos interessa mais, foi uma alteração importante na representação visual do diabo nos filmes. Até então, embora variasse bastante, a figura de Satã era representada quase sempre como humana - um homem sedutor e misterioso, às vezes assustador, às vezes exótico. Segundo Newman (2001, p. 41), O Exorcista tornou muito popular a segunda vertente representativa da figura do diabo, acentuando suas características sobrenaturais para mostra-lo como um monstro. O filme de William Friedkin é peça decisiva nas representações bestiais de Satã, conforme vista em títulos como A Lenda (Legend, Ridley Scott, 1985), As Bruxas de Eastwick (The Witches of Eastwick, George Miller, 1987) e Tenacious D-Uma Dupla Infernal (The Pick of Destiny, Liam Lynch, 2006).

Do ponto de vista do som, O Exorcista também foi, instantaneamente, um filme elogiado pela forma inovadora como tratou o personagem do diabo. O filme ganhou o Oscar de melhor mixagem sonora (trabalho assinado pelo veterano Robert Knudson e pelo então jovem Chris Newman, que depois se tornaria um dos sound mixers mais renomados da indústria cinematográfica norte-americana), e continua a ser lembrado como obra canônica em todas as três áreas cruciais da cadeia produtiva do som no cinema: música (à moda de Stanley Kubrick, o diretor William Friedkin recusou os temas originais compostos por Lalo Schifrin e usou música pré-existente escrita pelos compositores modernistas Krzysztof Penderecki e Anton Webern, além do conhecido tema instrumental Tubular Bells, de Mike Oldfield), efeitos sonoros (o foley produzido pelo artista mexicano Gonzalo Gavira, famoso pelo trabalho ouvido nos filmes do diretor vanguardista Alejandro Jodorowski, tem sido citado como um dos exemplos mais arrojados e criativos da área) e voz.

\section{A voz do diabo}

O uso da voz, em particular, demarcou uma inovação na representação vocal do diabo no cinema, e uma inovação que se mostraria muito influente na filmografia satânica que se seguiria. Trata-se de um dos primeiros casos cinematográficos, como notou Chion (1999, p. 169), em que a voz foi tratada pela equipe de produção como um efeito sonoro. Em todos os filmes feitos até então que tinham o diabo como personagem, a voz era providenciada pelo próprio ator que interpretava o papel; ainda que imprimisse um sotaque diferente, uma textura excêntrica ou um timbre sinistro, a unidade essencial entre voz e corpo - a sensação de que ambos são uma coisa só, indivisível - era devidamente preservada. 
Isso não ocorreu em $O$ Exorcista. No enredo muito conhecido do filme, como se sabe, uma garota de 12 anos (Linda Blair) é possuída por um demônio e submetida a um ritual católico de exorcismo. Para tornar crível a transformação física da criança no próprio diabo, William Friedkin tomou a decisão de retratá-la pouco a pouco como um monstro sobrenatural - um monstro que preservava algumas características físicas humanas, mas possuía o poder de transgredir essa humanidade (inclusive violando leis da física ou da fisiologia, levitando ou girando a cabeça em 360 graus em torno do pescoço) de forma repulsiva. Essa prática termina por caracterizar o afeto do horror propriamente dito. No aspecto visual, essa operação significou cobrir a atriz-mirim com chagas e feridas purulentas (uma imagem provavelmente inspirada no livro de Jó, do Antigo Testamento), o que a fazia parecer uma espécie de cadáver ambulante. A representação sonora do monstro diabólico, por sua vez, foi conseguida através da manipulação da voz do personagem, através de ferramentas estilísticas que tensionam - sem violar completamente - a centralidade do corpo reconstituído na tela como pivô das práticas tradicionais de representação sonora, conforme a clássica definição de Doane (1983, p. 458).

Durante as filmagens, Linda Blair foi dublada por uma atriz mais velha. Mercedes McCambridge não era apenas uma veterana de prestígio, dona de um Oscar ${ }^{3}$, mas também uma veterana oriunda do rádio. Para emprestar ao personagem o tom gutural, rascante e sobre-humano de voz que o diretor precisava, ela recorreu a truques elaborados por consultores de fonoaudiologia: comia ovos crus, fumava cigarros e bebia uísque antes das sessões de gravação (Kermode, 1999). No período de pós-produção, outros sons foram adicionados às falas do personagem: sussurros quase inaudíveis, trechos de frases faladas por outros atores de trás para frente e/ou com a velocidade de reprodução reduzida, além de gritos de porcos sendo abatidos e rugidos de leões. Todos esses ruídos, mixados cuidadosamente em conjunto, traduziam através do som o turbulento estado emocional-afetivo da personagem, algo explorado inteligentemente pelo roteiro escrito por William Peter Blatty.

As consequências desse trabalho artesanal se expandiram para muito além do Oscar de efeitos sonoros obtido pela equipe de pós-produção do filme. Tiveram, na realidade, um poderoso efeito sobre o modo naturalizado como o público até então percebia a voz - uma espécie de extensão natural e invisível do corpo do ator. Para Michel Chion, O Exorcista foi um dos três filmes dos anos

3 McCambridge venceu a categoria de atriz coadjuvante por A Grande llusão (All the King's Men, Robert Rossen, 1950) 
$1970^{4}$ que mais contribuíram para tornar o público consciente da autonomia da voz em relação ao corpo:

O Exorcista contribuiu significativamente para mostrar aos espectadores como a voz cinematográfica costuma ser associada rigidamente ao corpo cinematográfico. A união de elementos heterogêneos pode ser vista como o tema principal de O Exorcista. As audiências podiam deixar de encarar a voz como um elemento 'natural' que simplesmente saía do corpo (CHION, 1999, p. 164).

Em seu seminal estudo sobre a voz no cinema, Chion (1999) enfatiza como a voz era - e, podemos acrescentar, continua sendo - pouco estudada, mesmo pelos pesquisadores da área do som. Isso é especialmente irônico, já que é através dos diálogos que diretores e roteiristas costumam pôr em movimento a progressão dramática de qualquer ficção cinematográfica. De todo modo, por décadas, a voz foi (e ainda tem sido) percebida meramente como o veículo sônico utilizado pelos criadores para transmitir o enredo do filme.

É nesse sentido que o pesquisador francês posiciona a importância de filmes como $O$ Exorcista: ao chamar a atenção para aspectos não semânticos da voz - a respiração, o timbre, o sotaque, a textura acústica, a intensidade -, esses filmes trazem para o primeiro plano toda uma miríade de significados não verbais contidos na voz. Isso é particularmente notável nas sequências préexorcismo em que o diabo, na pele de Regan (Linda Blair), conversa com o padre Karras (Jason Miller): a ironia, a malícia e todo um rio subterrâneo de subtexto sexual e religioso estão contidos na voz, algo acentuado pelo fato de essa voz não corresponder à figura de cuja garganta emana:

[...] O Exorcista usa o processo de dublagem para fazer vozes múltiplas - mulher velha, monstro - sair da boca da menina possuída. Outros efeitos são tão velhos quanto o fonógrafo, como sons rodados ao contrário e em câmera lenta. O conjunto produz um efeito horrorífico devido à relação de estranheza que o expectador faz entre o corpo visível e a voz (CHION, 1999, p. 171).

Esta dissociação entre voz e corpo constitui uma das raras vezes em que um filme desnaturaliza a tese de que toda voz precisa de um corpo para existir

4 Os outros dois são Perdidos na Noite (Midnight Cowboy, John Schlesinger, 1969) e O Poderoso Chefão (The Godfather, Francis Ford Coppola, 1971), nos quais o cuidadoso trabalho vocal dos atores Dustin Hoffman (no primeiro) e Marlon Brando (no segundo) chamou a atenção para a forma como os intérpretes podiam modificar aspectos de suas vozes originais, como a entonação, o sotaque, o timbre e a textura acústica, para imprimir aspectos afetivos e/ou sensoriais mais adequados aos personagens da ficção. 
cinematograficamente. Mary Ann Doane cita dois tipos de vozes que atuam como exceção parcial dessa tese - a voz de Deus e a voz de um computador (Doane, 1983). Nos dois casos, porém, ela sugere que a representação visual dessas exceções quase sempre inclui figuras que se assemelham ao corpo humano - Deus tem sido representado como um homem velho e barbado, enquanto computadores quase sempre surgem com formas humanoides -, de forma que as vozes sem corpo desestabilizam a tese, mas não chegam a refutála. Nesse sentido, $O$ Exorcista surge pioneiramente como uma terceira exceção parcial.

Há no filme, contudo, pelo menos uma sequência que desafia abertamente a tese de Mary Ann Doane. Na cena, o padre Karras analisa, com o auxílio de um gravador Nagra, gravações da voz de Regan. Escutando detalhadamente essas gravações, em um equipamento tecnologicamente avançado que é capaz de isolar e reproduzir separadamente ruídos que ocupam diferentes frequências acústicas, o padre é capaz de identificar em segundo plano sonoro múltiplas vozes simultâneas aos sons emitidos pelas cordas vocais da garota. Há diálogos falados de trás para frente, e que parecem sair da garganta de pessoas distintas, inclusive homens. No plano da diegese, essas gravações funcionam como uma prova material da possessão diabólica do corpo da garota. No plano narrativo, porém, a sequência é ainda mais eficiente, pois explicita a natureza sobrenatural da personagem e reafirma, de modo bastante enfático, o afeto do horror - a repulsa, o medo, o inexplicável - desejado pelo filme.

\section{O diabo na música}

Em música, a representação sonora do diabólico é vasta e, obviamente, não se limita ao mundo cristão. As qualidades musicais tidas como "demoníacas" variam de cultura para cultura, quando não dentro de uma mesma tradição. $\mathrm{Na}$ música ocidental, por exemplo, o maléfico ressoou de muitas formas, de acordo com cada época. Dada à riqueza destas representações, destacaremos algumas particularidades antes de nos atermos especificamente ao filme de Friedkin.

O musicólogo Wilkins (1999) destaca que desde as mais remotas representações (iconográficas e escritas) é possível encontrar uma figura satânica que explora e/ou aprecia o poder da música, que a usa como forma de seduzir. Em tom irreverente, o autor diz que, no mundo musical, "le diable étant partout $^{5 \text { " }}(1999$, p.14) e que pode tanto materializar-se em uma melodia fugidia quanto naquele virtuose que toca como ninguém.

5 "O diabo está em toda parte". 
O catolicismo medieval tentou banir este "perigo" da igreja, afastando ritmos e instrumentos musicais dos seus hinos, bem como qualquer embelezamento que pudesse "distrair". O canto deveria ser simples e sensibilizar pelo conteúdo das palavras sacras. Dentre os maiores pecados do cantochão figurou o trítono (intervalo musical de três tons inteiros), considerado o diabolus in musica justamente por provocar polarizações e tensões na escala musical diatônica, implicando o que Wisnik denomina de "jogo de forças". Evitado a todo o custo, este intervalo, quase um tridente sonoro, é a antítese da oitava, que é um intervalo inteiramente estável. Ele a divide ao meio, gerando "a dissonância incontornável" (WISNIK, 1989, p.75).

Portanto, não é à toa que, desde Gesualdo (1566-1613) e Monteverdi (1567-1643), uma vasta gama de compositores ocidentais usaram trítonos para representar forças malignas, prática que ainda ecoa, principalmente no cinema. É o que ocorre, por exemplo, no começo do poema sinfônico Dança Macabra (1874), de Camille Saint-Saëns, quando um ente sobrenatural (muitas vezes interpretado como o diabo) toca várias vezes no violino um trítono (lá - mi bemol) como chamariz para os mortos iniciarem a tal dança da meia-noite. Esta peça, a exemplo de tantas outras, apareceu com frequência em compilações destinadas ao acompanhamento de filmes silenciosos, em geral com o indicativo de ser executada em cenas de horror ${ }^{6}$.

Em síntese, podemos dizer que várias das estratégias musicais tidas como diabólicas são frequentemente descritas em contextos que variam desde as escrituras sagradas, a iconografia medieval, o teatro elisabetano, o romance do século XIX e toda e qualquer representação narrativa que explore o mesmo tema. A música do diabo comporta, então, desde as trombetas e os tambores das portas do inferno, as liras e as flautas de anjos caídos, violinos virtuosísticos, órgãos e sinos majestosos, vozes graves e guturais, timbres etéreos, trinados, dissonâncias, reverberações e cacofonias variadas.

A lenda de Fausto foi um dos temas diabólicos mais recorrentes na música ocidental e um prato cheio para todas estas características e outras mais. Boa parte dos mefistos, em óperas e peças vocais, ganhou a voz de um baixo como marca sonora, melodias cromáticas, ritmos matreiros e risadas sinistras ${ }^{7}$. Em compensação, certas peças instrumentais evocam o diabo de forma não tão óbvia, com é o caso da Sinfonia Fausto (1857), de Franz Liszt. Nela, o Mefisto,

6 Um exemplo pode ser visto na página 237 da Encyclopedia of music for pictures, de Erno Rappé, publicada originalmente em 1925.

7 Exemplos podem ser encontrados nas óperas Fausto (Charles Gounod, 1859), Mefistófele (Arrigo Boito, 1868) e A Danação de Fausto (Hector Berlioz, 1946). 
retratado no terceiro e último movimento, não ganhou melodias 'próprias' e sim (literalmente) incorporou os temas de Fausto do primeiro movimento, distorcendo-os, fragmentando-os.

No cinema, cujo pacto com a música está em sua origem, a história se repete. As melodias diabólicas costumam revisitar conhecidos clichês, que não apenas sonorizam seres demoníacos, mas habitam as atmosferas sinistras e sobrenaturais dos filmes de horror de um modo geral, local onde é comum encontrarmos uma desestabilização da tonalidade, uma fragmentação ou dissolução melódica, uma tessitura instrumental (ou vocal) explorada em limites extremos e ruidosos, bem como efeitos como trêmulos, glissandos, clusters ${ }^{8}$. Kevin Donnelly defende que a música é um elemento vital no cinema de gênero, uma vez que funciona como um 'microcosmo' na constituição de códigos e na produção de efeitos fisiológicos (Donnelly, 2005, p.88). No entanto, muitas destas características musicais tidas como 'arrepiantes' são frequentes tanto na música acadêmica de vanguarda quanto na popular de cunho experimental, como o jazz e certas vertentes do rock, o que amplia ainda mais o espectro de possibilidades para as relações entre a música e o diabo.

Já especificamente sobre o diabo no cinema, Donnelly aponta um elemento peculiar: o fato de, muitas vezes, a música ser usada não apenas como um efeito ou dispositivo narrativo, mas como objeto invocatório que, como num ritual de magia, pode tanto chamar o demônio, ou ser parte de sua materialização. Um exemplo bem evidente deste uso ocorre em As Bodas de Satã (The Devil Rides Out, 1968), filme clássico do horror britânico dirigido por Fischer (2005).

Quanto ao uso da música em 0 Exorcista, as marcantes inovações deram-se graças à insistência do diretor que, resistindo à pressão da Warner, se recusou a usar os temas originais de Lalo Schifrin por achá-los, em certa medida, convencionais, tanto em relação às estratégias sonoras quanto aos momentos nos quais deveriam soar. De acordo com Beck (2010), Friedkin não queria uma música marcante e onipresente, tampouco como pano de fundo de diálogos e menos ainda nas cenas principais. Seu desejo era que houvesse uma ambiguidade entre os trechos musicais do filme e os efeitos sonoros, de tal modo que as fronteiras entre eles fossem borradas. Na sua concepção, os efeitos sonoros é que deveriam estimular as sensações no espectador e não

8 Sobre características gerais da música no cinema de horror, ver: CARREIRO, Rodrigo. “Sobre o som no cinema de horror: padrões recorrentes de estilo" in: Ciberlegenda (UFF. Online), v. 1, p. 43-53, 2011. 
uma música assustadora, principalmente porque parte do que ocorre no quarto de Regan não é visto, mas ouvido.

Logo na abertura, este artifício é acionado. Quando surge na tela o logo da Warner, um trecho do começo de Beginnings (from the Wind Harp), de Harry Bee, começa a soar (com alguns sons do ambiente mesclados, no final), seguido de algumas notas agudas em um violino. $E$, assim que o título do filme aparece, uma voz masculina canta, à capela, uma melodia em árabe. À medida que as imagens do Iraque são apresentadas, o canto vai cedendo espaço para o vento, as picaretas, os martelos, carrinhos de mão, vozerios e passos, supostamente motivados pelo ambiente que vemos (um sítio de escavações arqueológicas). Em seguida, enquanto acompanhamos o contato do padre Merrian (Max von Sydow) com representações do mal (um pequeno amuleto maléfico e, posteriormente, a estátua de um demônio), a atmosfera sonora mescla sons ritmados de ferreiros, burburinhos, cantos típicos, vento, passos e efeitos diversos, orquestrados com sutileza e lógica musical. De acordo com King (2010), Robert Knudson ${ }^{9}$ declarou que esta abertura foi concebida por Jack Nitzsche ${ }^{10}$ e que o músico, além de produzir alguns efeitos e compor pequenas passagens atonais, mesclou, junto ao som ambiente, fragmentos de uma peça de Krzysztof Penderecki e de músicas da região.

Ao longo da narrativa, os momentos com música não diegética são poucos, o que não impede que alguns sejam marcantes. Das peças pré-existentes ${ }^{11}$ que Friedkin optou por usar, oito pertencem ao repertório contemporâneo erudito: cinco são de Penderecki ${ }^{12}$, e as outras três de Hans Werner Henze, George Crumb $^{13}$ e Anton Webern ${ }^{14}$, respectivamente. No entanto, a música mais lembrada e associada ao filme é Tubular Bells, de Mike Oldfield, nome ligado ao rock progressivo.

Destas peças, pequenos trechos foram recortados e usados quase que exclusivamente em determinadas transições (entre cenas). Por serem breves demais ou estarem mesclados a outros sons, não é fácil reconhecê-los. Um dos que se sobressai pertence à primeira parte de Black Angels, de George Crumb, denominada Threnody I: night of the electric insects. Esta obra foi composta

$9 \quad$ Ele costuma assinar suas mixagens como Buzz Knudson.

10 Nitzsche criou vários efeitos que foram usados não apenas nesta sequência inicial.

11 A lista completa das músicas usadas no filme pode ser conferida em: http://www.imdb.com/title/ tt0070047/soundtrack?ref $=\mathrm{tt}$ trv snd

12 De acordo com os créditos do filme, são as seguintes: Kanon for Orchestra and Tape (1962), Cello Concerto (1966-67), String Quartet (1960), Polymorphia (1961) e The Devil of Loudon (1969).

13 Black Angels (1970).

14 Five pieces for orchestra op.10 (1911-13). 
em homenagem a jovens que lutaram na guerra do Vietnã e, embora Crumb use estratégias convencionalmente ligadas ao horror (trítonos, trinados e até um trecho baseado no hino gregoriano Dies (rae), a peça soa desconfortável graças a um rico experimentalismo que conta com a exploração de um quarteto de cordas amplificado e com o uso eventual de percussão, de sussurros e de objetos (copos de cristal, por exemplo). O trecho em questão aparece nos dois planos que mostram a frase "help me" no abdômen de Regan. De forma brusca, ouvimos cordas ásperas em registros extremos e dissonantes - pontuando o olhar espantado do padre Karras ao ver as letras em vergões na pele da garota.

Notas longas em ostinato são recorrentes em várias das breves transições. Aparecem geralmente oitavadas, com harmônicos e com algum intervalo dissonante (um trínono ou uma quinta aumentada, por exemplo). Estruturas semelhantes estão espalhadas pelas obras de Penderecki, como nos inícios de Polymorphia e da ópera The Devils of Loudon (1968), ou ainda em certas passagens do Kanon for string orchestra and tape (1962). Conforme já dissemos, é difícil precisar qual trecho está em qual passagem e se houve manipulação ou não na mixagem final.

Já a conhecida Tubular Bells aparece uma única vez durante o filme, de forma breve mas marcante. Seu retorno se dará somente na última parte dos créditos finais, estratégia que faz com que o espectador a ouça, desta vez, como uma espécie de epílogo da narrativa. A estranha e repetitiva melodia de Mike Oldfield, num tom menor e em um compasso nada óbvio (parece ser uma métrica em 15/8), inicia de forma suave, num único timbre de teclado que, aos poucos, duplica-se, sendo, posteriormente, acrescido pelo baixo. Lentamente, a melodia realiza progressões, mas mantém, por um longo tempo, a circularidade típica das composições minimalistas. Este vórtice sonoro pontua a primeira vez que, no filme, a mãe de Regan, Chris MacNeil (Ellen Burstyn), observa o padre Karras. Ela o vê na frente do prédio de 'tijolos vermelhos' (que fica atrás da igreja), conversando com outro padre sobre sua crise de fé.

Claire King, em ensaio que flerta com os Estudos Culturais, interpreta que a música, neste momento,'fala' pelos personagens problemáticos que vemos na tela, ao ecoar a conversa ansiosa dos padres e encorajar o espectador a observálos, como a mãe de Regan faz. Para a autora, que considera que o filme, além de nos contar a história de uma pré-adolescente que precisa de um exorcismo, aborda um mundo habitado por homens problemáticos (um padre com crise de fé, um diretor de cinema com problemas de orçamento e um detetive que se esforça em realizar o seu trabalho), o fragmento do Tubular Bells incorpora a melancolia destes homens, dando voz a uma subjetividade. Ao mesmo tempo, 
King acredita que a música é capaz de transcender este momento privado, o tornando coletivo, algo de uma "cultura inteira" (King, 2010, p. 121). No entanto, ela não enfatiza o como e o porquê a música de Mike Oldfield consegue tal façanha.

Na nossa leitura, certas características minimalistas da composição como, por exemplo, o ritmo assimétrico (apesar do pulso definido), uma nota repetida que cria uma sensação de imobilidade, a melodia circulante que passeia em torno de um eixo harmônico único, entre outras, guardam muitas semelhanças com o mundo modal. Nas palavras de Wisnik, há um "território sonoro" no minimalismo que retoma características da música modal que, por sua vez, tem fortes conexões culturais com a ideia de ritual. "Nas sociedades pré-modernas, um modo não é apenas um conjunto de notas, mas uma estrutura de recorrência sonora ritualizada por um uso ${ }^{15 "}$ (1989, p. 68). Tendo em vista esta aproximação, podemos supor que a melodia inicial do Tubular Bells é capaz de emular um caráter 'ritualístico', que tanto vai ao encontro da aura sobrenatural pretendida pela narrativa quanto, em certa medida, lança uma pista sobre o futuro destino do padre Karras: vivenciar um ritual que culminará em seu próprio sacrifício.

Wisnik destaca ainda que, no modalismo, as melodias são muito mais "manifestações da escala" do que "temas individualizados" (1989, p. 72), ou seja, tendem a ser sonoramente mais universais e menos específicas, algo que também podemos observar em técnicas minimalistas. Tal particularidade, a nosso ver, colabora para constituir a tal sensação coletiva apontada por King (2010).

Em suma, ao contrário do que poderíamos supor se levássemos em conta os chavões das representações satânicas no cinema, o uso da música em $O$ Exorcista não se vincula diretamente ao diabo. A constituição de sua atmosfera maligna não está atrelada à presença constante de uma música não diegética, por exemplo. Nem mesmo a materialização do demônio é por ela pontuada. Embora as peças citadas, por serem vanguardistas, contenham elementos amplamente difundidos como clichês do maléfico (atonalismo, dissolução melódica, tessitura além dos limites dos instrumentos, trêmulos, entre outros), elas pouco se conectam com a suposta presença do diabo na tela, mas sim com as angústias e temores dos outros personagens diante do desconhecido, tal como ocorre quando Chris ouve o médico de Regan sugerir um exorcismo, ou quando ela recebe a notícia de que Burke (Jack MacGowran), o diretor do filme no qual está atuando, está morto.

15 Grifo do autor. 


\section{Conclusão}

Newman (2001) nos lembra de que a possessão demoníaca, até então pouco retratada em filmes, depois do impacto comercial de $O$ Exorcista tornouse um filão recorrente no cinema de horror. Entre os títulos mais conhecidos que seguiram esta linha estão A Morte do Demônio (The Evil Dead, Sam Raimi, 1981), Stigmata (Rupert Wainwright, 1999), Fim dos Dias (End of Days, Peter Hyams, 1999), [Rec] 2 (Jaume Balagueró e Paco Plaza, 2009) e O Último Exorcismo (The Last Exorcism, Daniel Stamm, 2010), entre outros.

$\mathrm{Na}$ grande maioria destes filmes, os padrões de voz e de música estabelecidos por William Friedkin e sua equipe de som tornaram-se uma referência obrigatória para a representação sonora do diabo no cinema, sobretudo em situações de possessão, nas quais vozes guturais, duplicadas e falando línguas estranhas e/ou de trás para frente são frequentes. Apenas a título de exemplo, as múltiplas vozes ora graves, ora agudas entoadas pelos seres demoníacos do filme que Sam Raimi fez em 1981, e que por sua vez veio a se tornar um título muito influente para toda uma nova geração de cineastas de horror, derivam diretamente da representação sonora (e figurativa) da menina Regan.

No uso da música, o mesmo fenômeno aconteceu. Tubular Bells, de Mike Oldfield, seria um tema reutilizado em quase 40 filmes, muitas vezes criando um efeito de intertextualidade através do alusionismo ${ }^{16}$ (Carroll, 1998, p. 240) para inserir horror e suspense na trama. Além disso, toda a obra do compositor polonês Krzysztof Penderecki, até então pouquíssimo utilizada no cinema, foi associada a filmes de horror e suspense, muitos deles lidando com casos de possessão e transtorno de personalidade, como O lluminado (The shining, Stanley Kubrick, 1980) e llha do Medo (Shutter island, Martin Scorsese, 2010).

Isso nos leva a afirmar, sem dúvida, que o demoníaco no cinema, nas últimas cinco décadas, assumiu máscaras sonoras idênticas às do filme de William Friedkin. Inicialmente, é provável que o intuito de tal apropriação fosse exorcizar velhas fórmulas e/ou incorporar o sucesso da então novidade. Com o passar do tempo, no entanto, tal conchavo desenfreado, quer seja com as vozes múltiplas ou com o tom musical minimalista, tende a cobrar seu preço. Ao maléfico, portanto, talvez seja chegada a hora de novos disfarces.

16 Noel Carroll definiu o alusionismo como um termo que dá conta de práticas que incluem citações visuais e sonoras, homenagens explícitas ou implícitas e a criação de variações de cenas, planos, tramas, diálogos e temas de filmes do passado. 


\section{Referências}

BECK, Jay. "William Friedkin's The Exorcist and the Proprietary Nature of Sound". In: Cinephile, vol.6, $\mathrm{n}^{\circ}$ 1, Spring, 2010, p. 4-10.

CARREIRO, Rodrigo. "Sobre o som no cinema de horror: padrões recorrentes de estilo". Ciberlegenda, Rio de Janeiro (UFF), v. 1, 2011, p. 43-53. Disponível em: http:// www.uff.br/ciberlegenda/ojs/index.php/revista/article/view/38.Acesso em: 30 maio 2015.

CARROLL, Noël. Interpreting the Movie Image. Cambridge University Press: United Kingdom, 1998.

CHERRY, Brigid. Horror: Routledge Film Guidebooks. London: Routledge, 2009.

CHION, Michel. The Voice on Screen. New York: Columbia University Press, 1999.

DOANE, Mary Ann. "A voz no cinema: a articulação de corpo e espaço". In: XAVIER, Ismail (org.). A Experiência do Cinema. Rio de Janeiro: Edições Graal, 1983.

DONNELLY, Kevin. The Spectre of Sound: music in film and television. London: BFI Publishing, 2005.

GUERRA, Felipe M. O Diabo Também é Brasileiro: a figura de Satanás no cinema nacional. 2011. 174 f. Dissertação (Mestrado em Comunicação) - Universidade Anhembi Morumbi, 2011.

IMDb. O Exorcista (1973) Soundtracks. Disponível em: http://www.imdb.com/title/ tt0070047/soundtrack?ref=tttrvsnd. Acesso em: 5 de abril de 2015.

KERMODE, Mark. The Exorcist: BFI Modern Classics. London: BFI Publishing, 1999.

KING, Claire S. "Ramblin' Men and Piano Men: Crises of Music and Masculinity in The Exorcist". Music in the Horror Film: Listening to Fear (LERNER, N.). New York: Routledge, 2010.

LINK, Luther. O Diabo: A Máscara Sem Rosto. São Paulo: Companhia das Letras, 1995.

MITCHELL, Charles P. The Devil on Screen. New York: McFarland \& Co., 2002.

MUCHEMBLED, Robert. Uma História do Diabo: Século XII a XX. Rio de Janeiro: Editora Bom Texto, 2001.

NEWMAN, Kim. Nightmare Movies: Horror on Screen Since the 1960s. London: Bloomsbury Publishing Co, 2011. 
RAPPÉ, Erno. Encyclopedia of Music for Pictures. New York: Belwin, 1925 (reimpressão em 1970).

RICKELS, Lawrence. The Devil Notebooks. Minneapolis: University of Minneapolis Press, 2008.

SCHRECK, Nicholas. The Satanic Screen: an llustrated Guide to the Devil in Cinema. New York: Creation Books, 2001.

STANFORD, Peter. O Diabo: uma Biografia. Rio de Janeiro: Editora Gryphus, 2003.

WILKINS, Nigel. La Musique du Diable. Sprimont, Belgique: Mardaga, 1999.

WISNIK, José M. O Som e o Sentido. São Paulo: Circulo do Livro/Cia das Letras, 1989.

Recebido em: 7/6/2015

Aceito em: 12/6/2015

Endereço dos autores:

Rodrigo Carreiro <rcarreiro@gmail.com>

Suzana Reck Miranda <suzana_miranda@yahoo.com> 